\title{
AKTIVITAS PEMBINAAN KELOMPOK BERISIKO TINGGI MELALUI PROGRAM PENANGGULANGAN AIDS DI KABUPATEN KAMPAR
}

\author{
1) Azwar \\ ${ }^{1)}$ Manajemen Dakwah, Fakultas Dakwah dan Komunikasi, Universitas Islam Negeri Sultan Syarif Kasim Riau \\ 1) Jl. HR. Soebrantas KM 15 No 155 Tuah Madani - Pekanbaru - Riau - Indonesia \\ E-mail: Azwar.SE.MM@uin-suska.ac.id
}

\begin{abstract}
ABSTRAK
Penelitian ini dilaksanakan di Komisi Penanggulangan AIDS Kab. Kampar. Tujuan dari penelitian ini adalah untuk mengetahui aktivitas pembinaan kelompok berisiko tinggi melalui program penanggulangan AIDS oleh KPA Kabupaten Kampar. Penelitian ini menggunakan pendekatan kualitatif dengan menggunakan metode observasi dan wawancara terhadap Komisi Penanggulangan AIDS (KPA) Kabupaten Kampar. Artikel ini menunjukkan bahwa aktivitas - aktivitas pembinaan yang dilakukan adalah 1. Sosialisasi HIV dan AIDS kepada kelompok berisiko tinggi baik secara medis maupun agama, 2. Pemeriksaan darah bagi kelompok berisiko tinggi 3. Pedampingan kepada kelompok berisiko yang positif HIV, 4. Mewujudkan perubahan prilaku kearah yang lebih baik, ajakan untuk tidak lagi melakukan perbuatan zina, memperkuat keimanan kepada Allah dan memperbanyak amal sholeh. Rekomendasi dari Penelitian ini adalah supaya KPA Kabupaten Kampar lebih meningkatkan program-program yang telah dilaksanakan.
\end{abstract}

Kata Kunci: Aktivitas Pembinaan; Kelompok Berisiko Tinggi; Program Penanggulangan AIDS

\begin{abstract}
This research was conducted at the AIDS Commission of Kab. Kampar. The purpose of this study was to determine the activities of developing high-risk groups through the AIDS prevention program by KPA Kampar Regency. This study uses a qualitative approach using observation and interviews with the AIDS Commission (KPA) of Kampar Regency. This article shows that the coaching activities carried out are 1. HIV and AIDS socialization to highrisk groups both medically and religiously, 2. Blood tests for high-risk groups 3. Assistance to HIV-positive risk groups, 4. Realizing behavior change in a better direction, an invitation to no longer commit adultery, strengthen faith in Allah and increase pious deeds. The recommendation from this research is that KPA Kampar Regency further improve the programs that have been implemented.
\end{abstract}

Keyword: Coaching Activities; High Risk Group; AIDS Response Program

\section{PENDAHULUAN}

HIV atau Human Immunodeficiency Virus adalah virus yang menyerang sel darah putih di dalam tubuh (limfosit) yang mengakibatkan turunnya sistem kekebalan tubuh manusia. Orang yang di dalam darahnya terdapat virus HIV dapat tampak sehat namun orang tersebut dapat menularkan virus HIV kepada orang lain. AIDS atau Acquired Immune Deficiency Syndrome adalah sekumpulan gejala penyakit yang timbul karena turunnya kekebalan tubuh. AIDS disebabkan oleh infeksi HIV.

Penyebaran virus HIV dapat terjadi hubungan kontak darah antara penderita HIV dengan orang yang sehat, disamping itu juga virus HIV dapat menyebar melalui perzinahan (seks bebas), homoseksual (liwath). Prilaku-prilaku tersebut sangatlah dilarang dalam islam.

Kelompok berisiko tinggi adalah orang yang rentan terinfeksi virus HIV dan AIDS karena prilaku mereka yang jauh dari nilai-nilai agama islam seperti sering melakukan perzinahan (seks bebas), lelaki suka sama lelaki (homoseksual), menggunakan jarum suntik secara bersama pada saat mengkomsumsi narkoba.

Agama Islam adalah sebagai petunjuk bagi manusia untuk mencapai kehidupan yang 
bahagia baik didunia maupun diakhirat nanti. Islam adalah agama yang menyelesaikan semua masalah manusia, termasuk masalah HIV dan AIDS, sebagaimana firman Allah SWT dalam surat An - Nur ayat $30-31$ yang artinya :

Katakanlah kepada laki-laki yang beriman, agar mereka menjaga pandangannya, dan memelihara kemaluannya; yang demikian itu, lebih suci bagi mereka. Sungguh, Allah Maha Mengetahui apa yang mereka perbuat. Dan katakanlah kepada para perempuan yang beriman, agar mereka menjaga pandangannya, dan memelihara kemaluannya, dan janganlah menampakkan perhiasannya (auratnya), kecuali yang (biasa) terlihat (Q.S An Nur : 30-31)

Ayat diatas menunjukan bahwa HIV dan AIDS dapat dicegah dengan manusia menjaga pandangan agar tidak terjerumus ke perbuatan zina, dan bagi perempuan harus menutup auratnya. Dengan demikian virus HIV bisa dikendalikan. Namun sebaliknya jika kelompok berisiko tinggi tidak diberikan pengetahuan - pengetahuan tentang islam maka mereka akan selalu berada ditempat - tempat yang rentan tertular HIV dan akibatnya virus HIV di Kab. Kampar akan selalu meningkat.

Komisi Penanggulangan AIDS Kabupaten Kampar dibentuk berdasarkan Peraturan Presiden Republik Indonesia nomor 75 tahun 2006 dan Peraturan Menteri Dalam Negeri nomor 20 tahun 2007. Komisi Penanggulangan AIDS (KPA) Kabupaten Kampar adalah sebuah organisasi yang bergerak di bidang penanggulangan AIDS di Kabupaten Kampar. Banyak program yang dilaksanakan oleh organisasi ini dalam penanggulangan AIDS di Kabupaten Kampar antara lain adalah pencegahan dan penanggulangan HIV dan AID terhadap kelompok berisiko tinggi yang tersebar di Kabupaten Kampar. Kelompok berisiko tinggi adalah kelompok yang sangat rentan terhadap penularan HIV dan AIDS karena prilaku mereka yang melaksanakan seks bebas atau perzinahan.

Jumlah kasus HIV dan AIDS di Kab. Kampar sampai dengan Juli 2021 adalah kasus HIV berjumlah 102, sedangkan kasus AIDS sebanyak 22 orang. Menurut KPAN Fenomena gunung es terkait HIV dan AIDS berarti, bahwa orang terinfeksi HIV dan AIDS yang diketahui atau terlaporkan, hanyalah bagian kecil dari jumlah yang sebenarnya. Bagian yang lebih besar biasanya tersembunyi dan tidak diketahui jumlahnya. Jadi menurut teori epidemi tersebut di Kabupaten Kampar terdapat kasus HIV dan AIDS yang jauh lebih besar yang tidak terdeteksi.

Di Kabupaten Kampar tidak ada 1 (satu) pun tempat prostitusi yang dilegalkan, walaupun demikian keberadaan kelompok berisiko tinggi tidak bisa dihindari, berdasarkan informasi dari Komisi Penanggulangan AIDS Kab. Kampar kelompok berisiko tinggi ini tersebar dibeberapa Kecamatan. Jika kelompok berisiko tinggi terinfeksi oleh virus HIV maka mereka juga dapat menularkan virus HIV kepada orang - orang tidak berdosa seperti istri yang prilaku suaminya berisiko (berzina). Karena virus HIV bisa berpindah kepada orang lain selain hubungan seks berisiko (zina) juga bisa melalui darah.

Melihat lingkungan kelompok berisiko tinggi yang jauh dari nilai - nilai agama Islam dan kehidupan mereka selalu berpindah - pindah dan sulit untuk dijangkau maka penulis ingin mengetahui aktivitas pembinaan kelompok berisiko tinggi melalui program penanggulangan AIDS yang dilakukan oleh Komisi Penanggulangan AIDS di Kabupaten Kampar.

Studi sebelumnya yang dilakukan oleh Adi Prayitno Nugroho dengan judul " Pelaksanaan Pencegahan HIV dan AIDS Dalam Perspektif Pendidikan Agama Islam (Studi Kasus Pada 
Paguyuban Ojek Di Terminal Giwaangan)". hasil penelitian menyebutkan bahwa terwujudnya perubahan prilaku yang condong kearah yang lebih baik, memiliki kepedulian sosial, serta menjadi manusia yang sempurna (insan kamil) yang memiliki pengetahuan dan keperibadian islam (akhlakul karimah).

Penelitian yang dilakukan oleh Moch Zainal hakim, Rini Hartini R.A, Lina Favourita dan Nono Sutisna dengan judul "Prilaku Berisiko Tinggi Tertular HIV dan AIDS di Kalangan Supir Truk Antar Kota Antar Provinsi”. Hasil penelitian menyimpulkan bahwa kelompok berisiko tinggi mempunyai pengetahuan dan pemahaman yang sangat kurang terhadap HIV/AIDS. Studi terkait hal ini juga dilakukan oleh Ika Yuli Kumalasari dengan judul penelitian "Perilaku Berisiko Penyebab Human Immunodeficiency Virus (HIV) Positif (Studi Kasus Di Rumah Damai Kelurahan Cepoko Kecamatan Gunungpati Kota Semarang)". Hasil penelitiannya menyebutkan bahwa kelompok berisiko tinggi tertular HIV dan akhirnya menderita HIV positif karena perilaku berisko mereka menggunakan jarum suntik bergantian dengan temannya dan perilaku seksual mereka yaitu berganti-ganti pasangan seksual. Penelitian yang dilakukan oleh DM Sintha Kurnia Dewi, LPL Wulandari, Nyoman Mangku Karmaya dengan judul "Kerentanan perempuan terhadap penularan IMS dan HIV: Gambaran prilaku berisiko di Kota Denpasar”. Hasil penelitian menyebutkan bahwa gambaran perilaku berisiko yang menyebabkan kerentanan perempuan terhadap penularan IMS dan HIV adalah perilaku laki-laki yaitu hubungan seksual dengan lebih dari satu pasangan.

Penelitian ini akan membahas tentang aktivitas pembinaan kelompok berisiko tinggi melalui program penanggulangan AIDS di Kabupaten Kampar, penelitian ini akan menjelaskan aktivitas - aktivitas apa saja yang akan dilaksanakan oleh KPA Kab. Kampar dalam rangka membina kelompok berisiko tinggi sehingga mereka terbebas dari HIV dan AIDS dan bertaqwa kepada Allah SWT.

\section{METODE PELAKSANAAN}

Penelitian ini menggunakan pendekatan kualitatif, Sumber data dalam penelitian ini adalah sumber data primer dan sekunder. Teknik pengumpulan data adalah dengan menggunakan wawancara dengan pihak Komisi Penanggulangan AIDS Kab. Kampar. Kemudian sumber data sekunder adalah dengan mengumpulkan dokumen - dokumen terkait penelitian ini. Penelitian ini akan menjelaskan aktivitas-aktivitas pembinaan yang dilakukan melalui program penanggulangan HIV dan AIDS terhadap kelompok berisiko tinggi berdasarkan diskusi tanya jawab dengan pihak Komisi Penanggulangan AIDS Kabupaten Kampar.

Aktivitas - aktivitas yang didiskusikan kedalam beberapa pembahasan, 1. Sosialisasi HIV dan AIDS kepada kelompok berisiko tinggi, 2. Pemeriksaan darah bagi kelompok berisiko tinggi 3. Pedampingan kepada kelompok berisiko yang positif HIV, 4. Mewujudkan perubahan prilaku kearah yang lebih baik, ajakan untuk tidak lagi melakukan perbuatan zina, memperkuat keimanan kepada Allah dan memperbanyak amal sholeh. Adapun kerangka kerja pembinaan yang dilakukan adalah sebagai berikut :

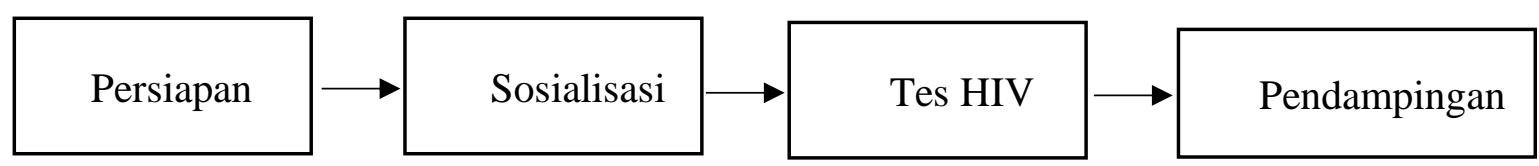

Gambar 1. Kerangka Kerja Pembinaan 


\section{HASIL}

\section{Sosialisasi kepada kelompok berisko tinggi.}

Pertumbuhan epidemi HIV di Indonesia sebagian besar disumbang melalui dua modus penularan: (1) penggunaan jarum dan alat suntik tidak steril pada pengguna napza suntik (penasun), dan (2) hubungan seksual. Namun demikian jika tidak dilakukan intervensi yang intensif, bukan tidak mungkin modus penularan lain akan terus meningkat.

Menurut Abzar dalam jurnal Rohimi dengan judul "Strategi Dakwah Tuan Guru Sujarman Dalam Meningkatkan Keagamaan Masyarakat (Studi Kasus Di Dusun Kelambi Desa Pandan Indah)" Idarotuna, Vol. 2, No. 1. jurnal tahun 2019, Dakwah merupakan tindakan yang bertujuan untuk mengajak orang- orang ke jalan yang benar. Dan secara terminologi dakwah Siti Muro"eah yang dikutip oleh M Abzar yakni merupakan pekerjaan yang menyerukan orang lain untuk berbuat yang baik dan meninggalkan yang mungkar. Sehingga ini tentu bukan pembinaan yang mudah untuk dilakukan kepada kelompok berisiko tinggi.

Kelompok berisiko tinggi adalah mereka yang sangat rentan terinfeksi virus HIV karena prilaku mereka yang jauh dari nilai - nilai agama Islam. Untuk menjangkau kelompok berisiko ini sangat sulit sekali karena kelompok berisiko ini selalu mengganti nomor telepon seluler dan selalu berpindah-pindah dari satu lokasi ke lokasi lainnya. Salah satu strategi untuk menjangkau mereka, KPA Kab. Kampar melakukan pemetaan dengan melibatkan kelompok dari mereka sendiri. Informasi yang didapat dari teman mereka maka dengan mudah untuk mengetahui keberadaan mereka yang lain. Kelompok ini tersebar dibeberapa Kecamatan di Kab. Kampar seperti di Kec. Tapung, Kec. Tapung Hulu, Kec. Tapung Hilir, Kec XIII Koto Kampar, Kec. Lifat Kain. Tempat tinggal mereka jauh dari pemukiman warga seperti dalam kebun sawit, di tepi jalan lintas. Setelah mereka dijangkau maka Komisi Penanggulangan AIDS Kabupaten Kampar akan mendata mereka dan memberikan memberikan sosialisasi kepada mereka. Sosialisasi yang diberikan kepada mereka terdiri dari sosialisasi secara medis dan agama. Secara medis yaitu memberikan informasi dasar terkait HIV dan AIDS dan cara penanggulangannya. Sosialisasi agama atau dakwah adalah kegiatan untuk mengajak kelompok berisiko tinggi untuk bertobat kepada Allah SWT, menjahui minuman beralkohol, menjahui perbuatan zina, narkoba. Tahapan sosialisasi yang dilaksanakan oleh Komisi Penanggulangan AIDS (KPA) Kab. Kampar terhadap kelompok berisiko tinggi selalu dilakukan dengan cara - cara persuasif dengan mengedepankan koordinasi atau tidak dengan cara - cara kekerasan yaitu sebagai berikut :

\section{Tahapan penentuan tempat}

Lingkungan hidup kelompok berisiko tinggi secara mayoritas tidak bergabung dengan lingkungan hidup masyarakat pada umumnya, tempat tinggal mereka jauh dari pemukiman masyarakat pada umumnya, mereka sering kali hidup berpindah dari suatu tempat ke tempat lainnya, hal ini mereka lakukan untuk menghindari razia dari petugas satpol PP. Mereka juga di kucilkan oleh masyarakat pada umumnya karena prilaku mereka yang jauh dari nilai - nilai Islam. Sosialisasi ke kelompok ini dilakukan disebuah rumah yang disepakati terlebih dahulu antara KPA Kab. Kampar dengan kelompok berisiko tinggi. Walaupun sudah disepakati KPA Kab. Kampar harus terus menjalin komunikasi lewat telepon seluler supaya mereka tidak membatalkan.

\section{Tahapan penentuan Waktu}

Pola hidup kelompok berisiko tinggi tidak sama dengan kelompok masyarakat pada umumnya. Kelompok masyarakat pada umumnya rata - rata tidur pukul 22.00 WIB dan 
bangunnya pukul 5.00 WIB. Kelompok berisiko tinggi malam harinya selalu pesta seperti bernyanyi di kafe - kafe, mengkomsumsi narkoba, mengkomsumsi minuman beralkohol, berjudi dan lain sebagainya sehingga kelompok ini tidurnya rata - rata Pukul 5.00 WIB bangunnya Pukul 12.00 WIB. Maka KPA Kab. Kampar dalam penentuan waktu ini berkoordinasi terlebih dahulu dengan kelompok ini sehingga kelompok ini bisa hadir semuanya dan mengikuti kegiatan dalam keadaan baik. Maka waktu pelaksanaan penyuluhan yang tepat untuk kelompok ini adalah sekitar Pukul 14.00 WIB atau setelah sholat zuhur.

\section{Tahapan penentuan Narasumber}

Mengingat bahwa zina atau hubungan seksual yang dilakukan kelompok ini adalah penyebab utama dalam penularan virus HIV, maka usaha yang sangat penting yang dilakukan adalah menyadarkan kelompok berisiko tinggi untuk tidak melakukan perbuatan zina atau seks bebas. Maka untuk pemilihan narasumber haruslah orang yang ahli di bidang HIV dan AIDS.

Pemilihan narasumber dalam penyampaian materi terhadap kelompok ini, KPA Kab. Kampar memilih 2 (dua) orang narasumber. Narasumber 1 (satu) adalah dari orang yang paham secara medis tentang HIV dan AIDS dan mampu menyampaikan materi kepada kelompok berisiko tinggi yang memiliki latar belakang yang berbeda. Narasumber 1 (satu), KPA Kab. Kampar meminta langsung kepada Kepala Dinas Kesehatan Kab. Kampar atau Direktur RSUD Bangkinang untuk menyampaikan materi HIV dan AIDS secara medis. Narasumber 2 (dua) adalah orang yang paham tentang HIV dan AIDS serta pandangan islam terhadap perilaku - perilaku perjudian, narkoba, perzinahan dan akhlak tercela lainnya. Narsumber 2 (dua) KPA Kab. Kampar akan memilih Ustadz yang memiliki kualifikasi dan kompetensi dibidang tersebut. Hal ini dilakukan melihat latar belakang kelompok berisiko tinggi sangat jauh dari nilai - nilai keislaman. Sehingga dengan 2 (dua) orang narasumber ini sosialisasi ke kelompok ini lebih komprehensif.

\section{Tahapan penentuan materi}

Terkait dengan penentuan materi sosialisasi yang akan disampaikan ke kelompok berisiko tinggi. Materi yang disampaikan ada secara umum dan ada secara khusus. Secara umum adalah upaya memberikan penerangan kepada kelompok berisiko tinggi tentang HIV dan AIDS baik secara medis maupun non medis atau pandangan islam terhadap HIV dan AIDS. Secara khusus adalah mendorong kelompok berisiko tinggi untuk tidak melakukan hubungan seks diluar nikah, secara homo, menghindarkan penyalahgunaan narkoba, apalagi suntikan, dan mendorong kelompok berisiko tinggi untuk pemeriksaan darah untuk mengetahui apakah mereka positf HIV 
atau tidak. hal ini dilakukan supaya sosialisasi ke kelompok ini lebih efektif.

Gambar 1. Sosialisasi Bagi Kelompok Berisiko Tinggi di Kec. XIII Koto Kampar.

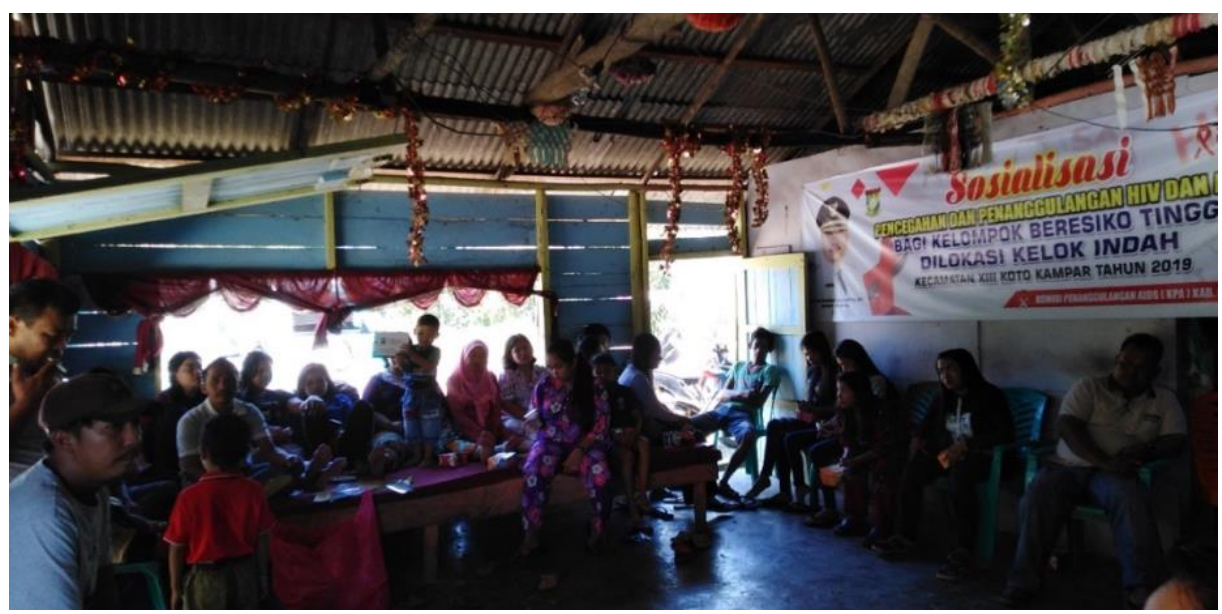

Gambar 2. Sosialisasi pencegahan dan penanggulangan HIV dan AIDS bagi kelompok berisiko tinggi di Kec. Tapung Hulu.

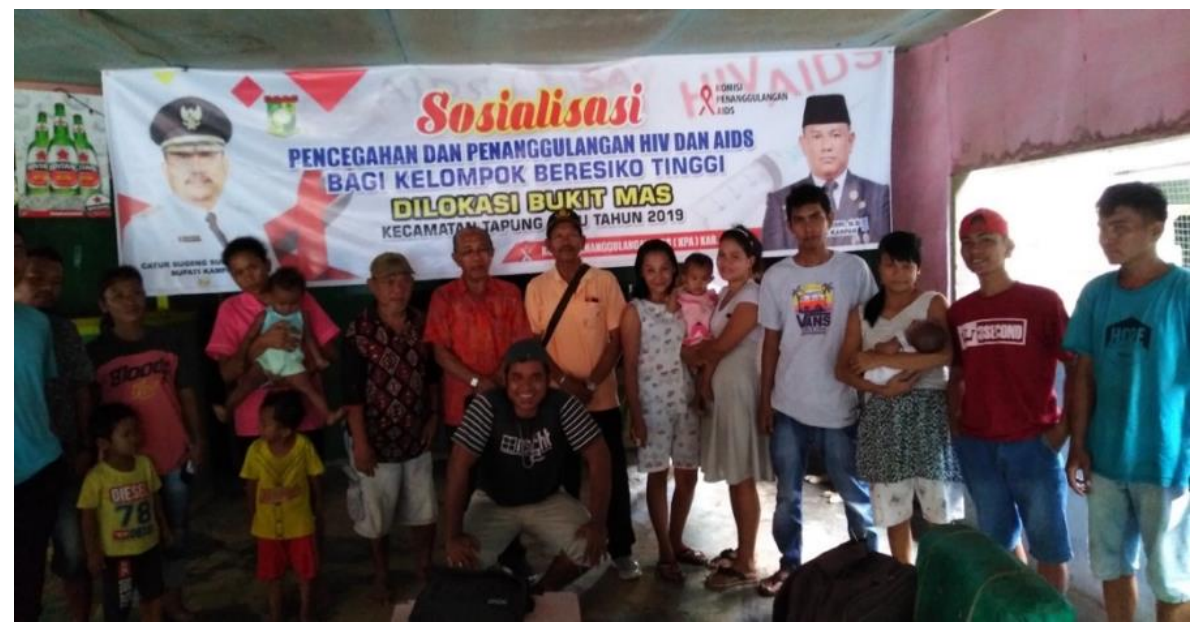

\section{Pemeriksaan darah bagi kelompok berisiko tinggi}

Setelah kelompok berisiko tinggi diberikan sosialisasi secara medis dan agama. KPA Kabupaten Kampar bekerja sama dengan tim klinik VCT RSUD Bangkinang untuk melakukan pemeriksaan darah. Pemeriksaan darah ini dikenal dengan istilah VCT. VCT (voluntary counselling and testing) adalah tes untuk mengetahui apakah seseorang terinfeksi virus HIV atau tidak. Kegiatan ini merupakan strategi penanggulangan AIDS bagi kelompok berisiko tinggi yang merupakan tindak lanjut dari program setelah sosialisasi diberikan. Tes ini mengandalkan kesadaran seseorang untuk mengetahui status kesehatannya. Setelah sampai dilokasi maka tim VCT RSUD Bangkinang melakukan prosedur VCT untuk tes HIV.

Prosedur yang dilakukan adalah 1, Sukarela artinya bahwa kelompok berisiko tinggi yang akan melakukan tes HIV haruslah berdasarkan atas kesadaran sendirinya, bukan paksaan atau tekanan pihak lain, bahwa kelompok berisiko tinggi setuju untuk dites HIV, apa keuntungan dan kerugian dari tes tersebut serta apa saja implikasi dari hasil positif atau negatif. Jadi pihak VCT akan menyiapkan informed consent (persetujuan tertulis) dari setiap kelompok berisiko tinggi sebelum 
dites, 2. Rahasia yaitu walaupun hasil tes nanti adalah positif maupun negatif hasilnya hanya boleh diberitahu langsung kepada orang yang bersangkutan. Tidak boleh diberikan dimelalui orang lain ataupun melalui telepon. Disamping itu juga hasil tes HIV dijamin kerahasiaannya oleh semua pihak yang terlibat dalam tes tersebut, hal itu itu dilakukan untuk melindungi hak asasi manusia dalam tes HIV ini. 3. Konseling sebelum tes yaitu konseling yang diberikan sebelum kelompok berisiko tinggi memutuskan untuk tes HIV atau tidak. Konseling ini dilakukan untuk membantu mereka untuk mengetahui risiko dari prilakunya selama ini, dan bagaimana nantinya bersikap setelah mengetahui hasil tes adalah positif HIV, 4. Konseling post-test, adalah konseling yang diberikan setelah hasilnya diketahui positif atau negatif. Konseling ini sangat penting untuk membantu mereka yang hasilnya positif supaya dapat mengetahui cara menghindari penularan kepada orang lain serta bisa mejalani pola hidup sehat. Sedangkan jika hasilnya negatif supaya kelompok berisiko tinggi menghidari tentang cara - cara mencegah terinfeksi dari virus HIV.

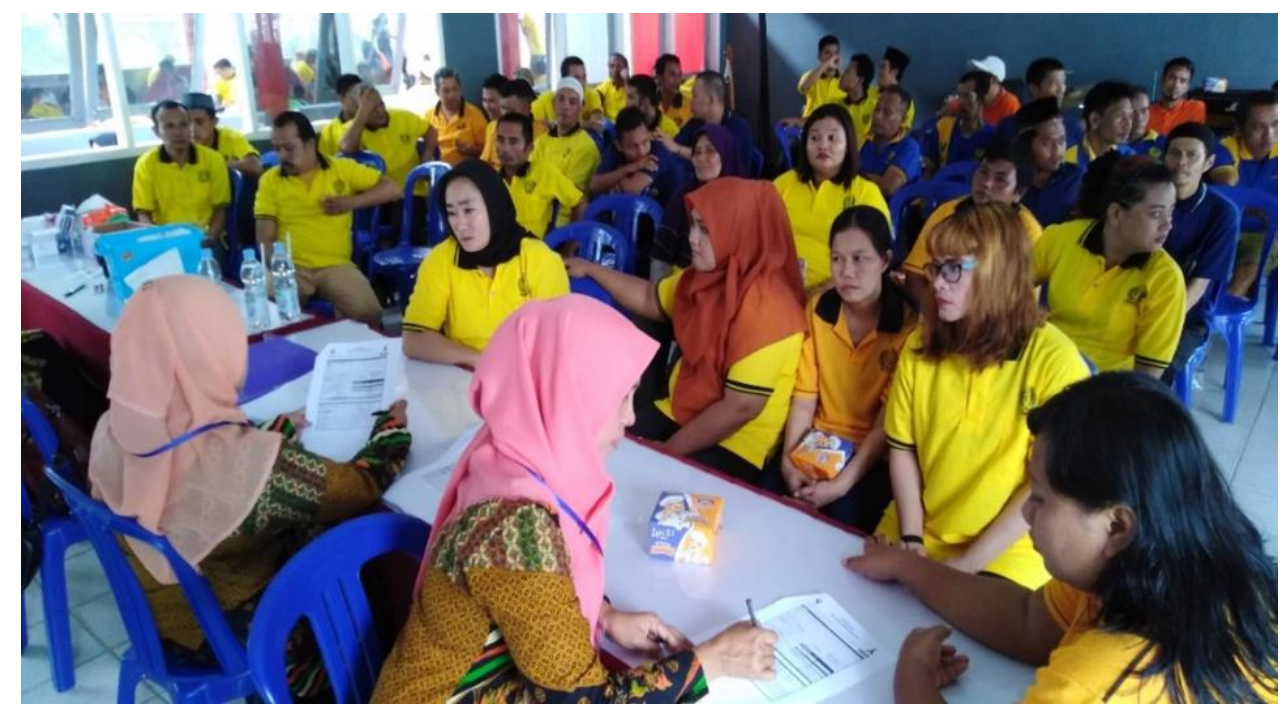

Gambar. 3 Pelaksanaan kegiatan mobile VCT di Lembaga Permasyarakatan Bangkinang

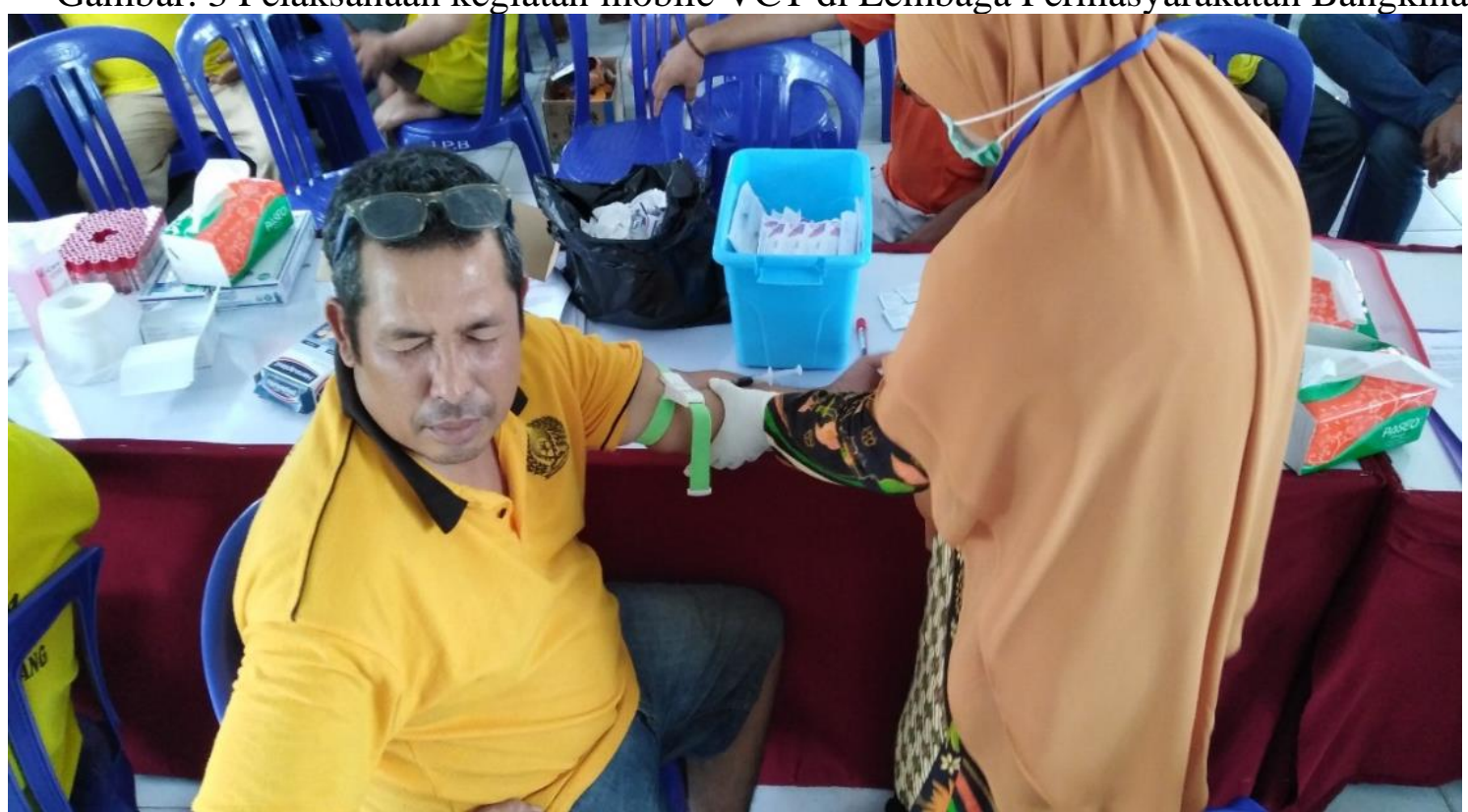

Gambar 4 Pelaksanaan kegiatan mobile VCT di Lembaga Permasyarakatan Bangkinang

Pedampingan kepada kelompok berisiko yang positif HIV.

Kelompok berisiko tinggi yang hasilnya positif HIV maka akan ditindak lanjuti 
oleh klinik VCT RSUD Bangkinang. Mereka akan diberikan obat Antiretroviral (ARV) secara gratis. ARV adalah obat yang diberikan secara gratis untuk : 1. Untuk menurunkan angka kesakitan dan kematian yang berhubungan dengan HIV, 2. Memperbaiki kualitas ODHA, 3. Memulihkan dan/atau memelihara fungsi kekebalan tubuh, 3. Menekan reflikasi virus secara maksimal dan terus menerus, 4. Menekan laju penularan HIV di masyarakat.

Tempat tinggal kelompok bersiko yang positif HIV ini sangat jauh dari klinik VCT RSUD Bangkinang, mereka ada yang tinggal di Kec, XIII Koto Kampar, Kac. Tapung, Kec. Tapung Hulu. Untuk mengatasi masalah - masalah yang dihadapi oleh kelompok berisiko tinggi yang positif HIV untuk akses layanan VCT di RSUD Bangkinang maka KPA Kab. Kampar menunjuk 1 (satu) orang petugas untuk mendampingi mereka seperti mengambil obat ARV, konsultasi masalah kesehatan mereka ke klinik VCT RSUD Bangkinang, Pendampingan ini dilakukan juga untuk memberikan dukungan psikologis bagi ODHA untuk selalu berprilaku hidup sehat dan tidak menyebarkan virus HIV ke orang lain. Disamping itu juga pendamping ODHA bertugas mendorong orang yang terinfeksi HIV untuk selalu mendekatkan diri kepada Allah SW

\section{KESIMPULAN}

Jumlah kasus HIV dan AIDS di Kab. Kampar sampai dengan Juli 2020 adalah kasus HIV berjumlah 102, sedangkan kasus AIDS sebanyak 22 orang. Salah satu penyebab seseorang terinfeksi virus HIV adalah melakukan hubungan seks bebas yang dilakukan oleh kelompok berisiko tinggi. Di Kabupaten Kelompok berisiko tinggi tersebar dibeberapa kecamatan di Kabupaten Kampar. Usaha yang efektif untuk mengatasi permasalahan HIV dan AIDS adalah mengembalikan prilaku manusia kepada prilaku yang sesuai dengan nilai - nilai islam disamping memberikan sosialisasi HIV dan AIDS kepada masyarakat.

Komisi Penanggulangan AIDS Kabupaten Kampar sangat berperan dalam mengatasi setiap permasalahan HIV dan AIDS di Kabupaten Kampar dengan bekerja sama dengan pihak pihak terkait untuk selalu bersinergi dalam melaksanakan program HIV dan AIDS di Kabupaten Kampar terutama bagi kelompok berisiko tinggi. Adapun strategi - strategi yang dilakukan adalah :1. Sosialisasi HIV dan AIDS kepada kelompok berisiko tinggi, 2. Pemeriksaan darah bagi kelompok berisiko tinggi 3. Pedampingan kepada kelompok berisiko yang positif HIV, 4. menanamkan nilai - nilai islam yaitu terwujudnya perubahan prilaku kearah yang lebih baik, ajakan untuk tidak lagi melakukan perbuatan zina, taubat kepada Allah dan memperbanyak amal sholeh

\section{DAFTAR PUSTAKA}

[1] Dewi, Kurnia Sinta DM., Wulandari, LPL., \& Karmaya, Mangku Nyoman. (2013). Kerentanan perempuan terhadap penularan IMS dan HIV : Gambaran prilaku berisiko di Kota Denpasar. Public Health and Preventive Medicine Archive, Volume 1, Nomor 1, Juli 2013.

[2] Hakim, Zainal Moch., Hartini, Rini R.A., Favourita, Lina, Sutisno, Nono. (2012). Perilaku Berisiko Tinggi Tertular HIV dan AIDS Di Kalangan Supir Truk Antar Kota Antar Provinsi. Jurnal Ilmiah Pekerjaan Sosial Volume 11 Nomor 2.

[3] KPAN. (2012). Laporan Kegiatan 2013, Jakarta : KPAN.

[4] KPAN (2011). Kurikulum Dan Modul Pelatihan Pokja PMTS Provinsi dan Kabupaten/Kota. Jakarta: KPAN. 
[5] KPAN (2011). Pedoman Advokasi Penanggulangan HIV dan AIDS 2011. Jakarta : KPAN.

[6] KPAN (2011). Agenda Nasional Penelitian HIV / AIDS 2010-2014. Jakarta : KPAN.

[7] KPAN (2011). Upaya Penanggulangan HIV dan AIDS di Indonesia 2006 - 2011: Laporan 5 Tahun Pelaksanaan Peraturan Presiden No. 75/2006 Tentang Komisi Penanggulangan AIDS Nasional. Jakarta : KPAN.

[8] Kumalasari, Ika Yuli, (2013). Perilaku Berisiko Penyebab Human Immunodeficiency Virus (HIV) Positif (Studi Kasus Di Rumah Damai Kelurahan Cepoko Kecamatan Gunungpati Kota Semarang). Universitas Negeri Semarang, Semarang, Indonesia.

[9] Nugroho, Adi Prayitno. (2015). Pelaksanaan Pencegahan HIV dan AIDS Dalam Perspektif Pendidikan Agama Islam (Studi Kasus Pada Paguyuban Ojek Di Terminal Giwaangan). Universitas Islam Negeri Sunan Kalijaga Yogyakarta, Yogyakarta, Indonesia.

[10] Rohimi (2019). Strategi Dakwah Tuan Guru Sujarman Dalam Meningkatkan Keagamaan Masyarakat (Studi Kasus Di Dusun Kelambi Desa Pandan Indah). Idarotuna, Vol. 2, No. 1. 